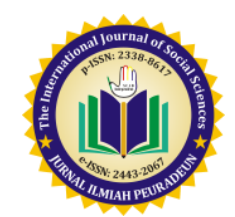

\title{
DEVELOPMENT MODEL OF PASRAMAN KILAT LEARNING TO IMPROVE THE SPIRITUAL VALUES OF HINDU YOUTH
}

\author{
I Ketut Sudarsana \\ Lecturer at Denpasar State Hindu Dharma Institute \\ Email: ulakan82@gmail.com
}

Received: Feb 24, 2016

Accepted: Apr 07, 2016

Published: May 28, 2016

Article Url: https://journal.scadindependent.org/index.php/jipeuradeun/article/view/99

\begin{abstract}
Human resource development is one that can be implemented through the implementation of non-formal education, in this case is pasraman kilat which is expected to enhance the spiritual values. Methodologically this study is using the procedure of research and development, where the stages include: (1) A preliminary study, (2) Preparation of a conceptual model, (3) Validation and revision of the model, (4) Testing the model, (5) Revision of the model, and (6) The final model of pasraman kilat. This study managed to describe (1) The pasraman kilat has not fully follow the principles of good learning, such as planning, implementation and evaluation. (2) The conceptual model was developed using pasraman kilat participatory approach which is expected to bring about change in the planning, implementation and evaluation. (3) Implementation of pasraman kilat model is showing success. It is characterized by the achievement of such indicators; a) planning, b) implementation and $c$ ) evaluation. The effectiveness of pasraman kilat models indicated by the positive impact of both the participants and the organizers of pasraman kilat.
\end{abstract}

Keywords: Pasraman Kilat and Spiritual Values 


\section{A. Introduction}

By nature, people in general will experience some phases of development that requires mental preparation to deal with it. Among the development phase are not all can be passed smoothly, because there is some teenagers found in a phase of a mental instability, resulting some symptoms and characteristics that lead to the negative. According to Marheni (2010: 47) "personal tendencies, talents and roles are given to adolescents, both by parents, peers and the community in turn can give direction and meaning in the life for the future".

Problems that arise in adolescents in development according to Hurlock (1991: 95) are: First, the personal problems is relating to the circumstances at home, school, physical condition, appearance, emotional, social adjustment, assignment and values. Second, the typical teenage problems, that arising from the unclear status in adolescents, such as the attainment of independence issues, misconceptions or false judgments based on stereotypes, the rights of which are larger and fewer obligations imposed by parents.

Surely not all of the orientation change have negative tendencies. In this era of globalization with global information, orientation changes occur as a result of the shift in interests. A positive value for teens depending on how they perceive and implement the results of learning/ education in the life of a teenager. This is because the real education will determine the direction of development and identity formation of adolescents. Moving on from the statement, it is understood how religious education is needed to form the human moral and decency. Through appreciation and practice of religious teaching adolescent mental balance can be expected to grow naturally, so that from it will have an impact on the way of thinking and behaving.

Related to the emergence of the phenomenon of juvenile delinquency in fact cannot be separated from the weak role of religious education for the youth. Religious education at school and in the family did not fully succeed in forming a good moral. Religious education as one of the activities to build a solid foundation of spiritual mental, cannot contribute to the fullest. A very real indicator is the increasing number of students who are involved in criminal acts, such as fights, drug use, robbery and others.

According to Arif (1995: 98-100) various factors that cause the lack of effective religious education in schools, among others: First internal factors, ie 
the factors that emerged from within the religious teachers include: competence of teachers are relatively weak, management misuse of religious teacher, methodological approach of teachers who are not able to attract students to the teaching of religion, the religion teacher solidarity with nonreligious teachers are still very low. Both external factors, which include the attitude of the community/ parents who are less concerned about the continuing religious education, the environmental situation around the school gives many bad influences, as well as the negative influence of technology development, like internet, play station and others. Third, institutional factors, which include at least the allocation of teaching hours of religious education and curriculum that are too overloaded.

Lack of effective religious education as described above, in turn raised concerns about the mentality of the nation in the future. Therefore, the implementation of religious education at various levels of education deserves to be refined. This can be done by looking for other alternative learning model that can support the effectiveness of the implementation of religious education. One model of learning that can be used as alternative learning models support is pasraman kilat. This model was chosen on the basis of the reality that the majority of the villages/ wards throughout Bali every year organizes pasraman kilat, so in terms of quantitative, pasraman kilat is a potential model to be developed.

Pasraman kilat is one form of school education that aims to provide guidance to adolescents religion deliberately at a certain level towards a balance between religious theory gained in formal school with practice mandated by religion through pasraman. Pasraman kilat itself is one level of school education that is offered as a medium for young people to experiment on matters concerning religion.

On the basis of the various factors mentioned above, pasraman kilat express the expectations of an alternative organization of religious education at school, it has not been implemented optimally. This occurs because to date, no model design of pasraman kilat formulated systematically, so that various educational institutions organize pasraman kilat, designed it with their own. Therefore, a comprehensive model of pasraman kilat is needed so that it can be adopted in implementing pasraman kilat. 


\section{B. Research Method}

Research procedures used to support this research is the research and development ( $\mathrm{R} \& \mathrm{D})$, which is developing a learning model of pasraman kilat which is innovative and effective in the development of spiritual values to Hindu teenagers in Padangsambian, Denpasar. Procedures R \& D used in this study is a procedure set by Borg and Gall (1983: 25), namely: First, a preliminary study, which is to obtain empirical data and theoretical about the condition of Hindu youth and pasraman kilat have been carried out previously in Padangsambian. Second, preparing a conceptual model that will be implemented. Third, revise the model based on inputs from experts until the model is ready to be tested. Fourth, test models. Fifth, a revised model of the analysis and refinement of the model based on the test results. Sixth, the final model of learning of pasraman kilat is to enhance the spiritual values of Hindu teenager in Padangsambian, Denpasar.

This research is basically done in a planned and scientific, which starts from the process of collecting data and facts relating to the existence of Hindu teenagers and pasraman kilat that have been implemented over years. Form experimental design used in this study are the Pre-Experimental Designs (nondesigns), where these forms are used in the process of testing a pasraman kilat models that have been developed. The goal is to see the effectiveness of the learning model pasraman kilat, so expect to obtain good pasraman kilat models and effective. Pre-Experimental Designs form (non-designs) used in this study is the One-group pretest-posttest design. This design is done by comparing the results of pretest to posttest results of tests on groups that have been tested, and does not use a control group.

\section{Research Finding and Discussion}

1. Learning Objective Conditions in Pasraman Kilat Padangsambian, Denpasar

Pasraman kilat as non-formal education by Pasraman can be implemented in Pura, studio or other place that allows the implementation of the learning process. Padangsambian village which is the bottom of the governance structure in the annual program has been carrying out development based on policies/ rules outlined above. For 
realization of religious education, Padangsambian village such as other villages in Bali in the annual work programs of pasraman kilat always carry nuancedof culture and Hinduism.

Based on kilat pasraman documents and interviews, showed that pasraman kilat is implemented by the Padangsambian village still has some drawbacks, which are as follows:

a. Pasraman Target

As a program funded by the government on a regular basis every year, pasraman kilat implemented only seen in terms of quantity, so the success of pasraman kilat just in view of how much participants is coming. No specified characteristics of the participants is allowed to follow pasraman kilat, so that the participants of young adults with young teens and the less educated to the uneducated.

\section{b. Preparation of Learning Programs}

Learning programs that became the core ofpasraman kilat not collated based on the needs of the participants, this is due to the determination of the program such as materials, methods, timing and learning resources, organizers do not involve the participants in the plan. Learning plans are essentially a short-term planning is done by the facilitator to be able to estimate the various actions to be carried out both in class and outside class, designed by the organizers only.

\section{c. Material of Pasraman Kilat}

Pasraman kilat that is implemented more focused on the goal of gaining knowledge for the benefit of individual. It is clear that spiritual behavior has not been a priority in the implementation of pasraman kilat.

\section{d. Learning Activities}

Participants in the learning activities are treated just as an object of study, not the subject of learning, so active participants not be optimal. In addition, the learning method that is used is limited only at the end of the exposure lecture occasionally punctuated by questions and answers, this causes less participative learning atmosphere. Pasraman kilat related to 
skills, the presentation of the material is only a theory and not enough practice. More participants are assumed to have mastered the skills in making upakara, so the preferred practice is done at home respectively.

\section{e. Pasraman Kilat Timing}

Pasraman kilat timing is determined directly by the organizers without involving participants in its determination, this resulted in many participants were not optimal presence in the span of pasraman kilat implemented. Whereas the level of attendance of participants in the learning process is determine the success of pasraman implemented.

\section{f. Evaluation}

Learning that has been implemented by participants of pasraman kilat does not end the process of evaluation, even though the nature of the evaluation is to describe the process, collect and present information on the implementation of a learning process for consideration in the decisionmaking further learning. So that the evaluation is not implemented, then both the participants and the facilitator does not know the extent of progress, development and achievement of learning have also not implemented. Beside that also the evaluation is implemented in pasraman kilat, causing the organizers do not know the advantages and disadvantages of pasraman kilat that have been implemented so far.

Referring to the above, it can be concluded that the objective conditions of pasraman kilat conducted by the Padangsambian Village not fully follow the principles of good pasraman kilat. In addition pasraman kilat implemented yet the aspect of the educational value of Hinduism, whereas the participants of pasraman kilat should pay attention to spiritual values. On the basis of the findings of the preliminary study, then pasraman kilat model development is to enhance the spiritual values in Padangsambian to Hindu teenager. This development is based on the consideration that pasraman kilat model as the implementation of nonformal education provides answers to the lack of formal religious education within reach all school-age children, and the failure to form a religious resources. 
Research questions about the objective conditions of pasraman kilat in Padangsambian Village, Denpasar have gone unanswered in the results, where pasraman kilat that have been implemented so far generally not been applying the principles of learning, such as planning, implementation and evaluation well. The other thing is not focused the target of pasraman kilat implemented, where pasraman kilat look like success only in view of the quantity of people who attend and follow pasraman kilat. Pasraman kilat implementation also does not touched on aspects of the internalization of the real value of the Hindu religion which is very important for participants in enhancing the spiritual values. Pasraman kilat nature is not just a transfer of knowledge, but also as a vehicle to internalize the values as well, especially Hinduism value to increase spirituality. Besides that, the organizers did not provide exemplary as a hidden curriculum that can strengthen the internalization of those values, which organizes the program is not in accordance with the guidelines, data manipulation activities, and other irregularities that led the goal of the program itself cannot be implemented due to the negligence of the organizers of pasraman kilat.

\section{Conceptual Model of Pasraman Kilat Learning to Increase Spiritual Values of Hindu Youth in Padangsambian, Denpasar}

Preparation of the conceptual model in pasraman is very important, this is due, among others: First, the conceptual model is closely related to references used. With the help of conceptual models, researchers are able to show how to look at the phenomena presented in the research theoretical. Concept used to build a conceptual model gives perspective to see the empirical phenomena. Second, the conceptual model can help in structuring the problem, identifying the relevant factors, and then give the relationship that makes it easier to see the problem. Furthermore, the model will help simplify the problem by reducing the number of properties that should be included, so that it is easier to focus on things that are essential. Third, connect it to the system theory (Jan Jonker, et al: 2011: 98).

The conceptual model creates a reality in the sense of collective understanding. This is due to the conceptual model that is based on the 
language derived from the theoretical understanding. Without any theoretical input, then it is impossible to make a construction that focuses on a reality. It can be concluded that the conceptual model is a framework that builds upon the theoretical framework that describes the relationship or linkage models the variables used in the study. The conceptual model of pasraman kilat that is developed based on aguron-guron or asewakadharma system is trying to offer in order to overcome the objective conditions of pasraman kilat that had been implemented, would be expected to bring a change, either in the planning, implementation and evaluation.

The conceptual model of learning is trying to express pasraman kilat designed and developed in general by implementing three basic steps of pasraman kilat implementation, including planning, implementation and evaluation. The first step of the stages of preparation of the conceptual model of learning pasraman kilat is to carry out the identification of the needs of pasraman kilat whose benefits include; 1) Obtaining data on the problems and needs are desired by the target, 2) To make it easier to determine priorities in program planning activities, and 3) Facilitate the implementation of activities.

In the context of pasraman kilat, the main thing to do is to prepare the participants such that motivation grow and develop optimally, and can have an impact on improving the knowledge, skills and attitudes. This is in line with the opinion of Jacius (1974: 296), which mentions the term "education shows a process of improving attitudes, abilities, and skills to carry out the work in particular". This expression indicates if pasraman kilat is a process to help young Hindu to gain effectiveness in conducting, both in the present and the future through the development of habits of thought and action, skills, knowledge, and attitude.

Organizers and facilitators of pasraman kilat must be able to cultivate the willingness of participants to conduct this study. Every moment should give an injection of enthusiasm or motivation to adolescents who participated in pasraman kilat to undergo activities. This certainly is not light work because the lifestyle of teenagers today are generally more inclined to instantiation, want fast-paced and available to them without willing to work hard. 


\section{Implementation of Pasraman KilatLearning Model to Increase Spiritual Values of Hindu Youth.}

Pasraman kilat system that is developed in the implementation of the learning model of pasraman is aguron-guron or asewakadharma, which means that the quest for knowledge and skills, ongoing in various places and times by way of a person who intentionally knowledgeable and skillful. In pasraman kilat, the system of aguron-guron or asewakadharma carried out before, during and after pasraman. This thing indicates that pasraman kilat participants involved in the search of knowledge and skills from planning, implementation, evaluation and post pasraman.

The concept of aguron-guron or asewakadharma actually a strategy that can be taken to improve the quality of human resources through nonformal education, which is carrying out an ongoing learning. Aguron guron or asewakadharma is a broad term and is used to describe the process of continuous learning, personal enrichment and the expansion of knowledge and skills continuously. Relationship facilitators and participants did not stop after the implementation of pasraman kilat ended, but continues in the context of gurusisya, the close relationship between the facilitator and participants of pasraman.

Guru sisya implies an ongoing relationship between the facilitator and participants in order to establish active communication and motivation and endless learning. Through this relationship allows the facilitator to continue to provide guidance for the achievement of the objectives of pasraman kilat for Hindu teenager independent and able to enhance spiritual values. These relations cannot be separated from motivation and participation were successfully built by facilitators and participants of pasraman kilat.

Aguron-guron or asewakadharma system is in accordance with Wratisasana teachings in some cases referred to as follows: a) Participants stressed about the perseverance to learn from the beginning to the post of pasraman kilat. b) Life studied required to force holy inwardly and outwardly away from all sin and immoral behavior. c) Arranged to be able to live a simple, not fancy in life. d) It is not justified to neglect, especially in the worship 
of God. e) Diligent study (swadhaya), diligent abstinence and upawasa (fasting), and diligently concentrate (dhyana). Similarly, for a facilitator is also taught to be careful and need to provide rules on the participants to improve selfdiscipline and strengthen the spirit of learning.

Implementation of the pilot model of the number of 20 participants was held on 1 until 10 July, 2015, is the estuary of the entire stage of planning. Everything already formulated in the planning of a reference in the implementation of pasraman kilat. Before the learning process started, first performed the opening, the condition with the technical explanations by researchers associated with pasraman kilat implementation and evaluation processes. This is followed by a word from the headman of Padangsambian which also opened pasraman kilat.

The order of execution of the routine meetings of pasraman kilat activity includes opening activities, the core activities and ending activities. Opening activities conducted by the facilitator pasraman include: greetings by saying in Sanskrit "Om Swastyastu" which means hopefully always in good working order for the gift of God, the implementation of common prayer, examination attendance, fostering familiarity which aims to condition the attendant of pasraman to follow the learning, do apperception by connecting everyday experience with the material to be learned and convey the purpose of pasraman.

At the core activities, covering: facilitators deliver teaching materials systematically through andragogi approach using participatory learning. The facilitator asks the feedback from participants of pasraman, accompanied by observing and helping participants of pasraman in problem solving, tasks or demonstrations. Facilitators provide motivation to the participants of pasraman to learn and listen attentively and participate in any learning process is implemented. Facilitators provide the motivation to always do good according to religious teachings. Facilitator strengthen pasraman results by giving praise to participants of pasraman, asking and trying to answer all the problems and things that are not yet clear that faced by participants.

In the closing activity, the facilitator carry out an evaluation of the material that has been exposed, through the questions that must be answered by 
the participants of pasraman orally. Subsequently conducted a review of pasraman material that has been learned together, and deliver conclusions and closing of learning in a meeting of pasraman kilat by saying thank you, apology and gratitude the presence of God. Finally, the facilitator with the participants of pasraman spruce media/ appliance store and learning materials in a special file for further use, place it back clean and orderly.

Opening activity, core activities, and ending activities in every learning process is repeated every time a meeting for 10 days, with little difference in the level of the method implemented which began at the meeting of 8 till the 10th more focused on the practice of the ceremony, as well as in the meeting of 9 of pasraman participants are invited to visit the field. Any discussion of the material, the facilitator always incorporate and emphasize the importance of values implemented in the spiritual field. Visiting program of pasraman kilat is visiting upakara businessmen in Padangsambian.

Related to the internalization of values in pasraman kilat, means used are (1) the facilitator provide advice relating to the values that are developed, (2) a facilitator and organizer of pasraman provide examples of exemplary, (3) keeping together habituation good, (4) facilitators and organizers of pasraman provide motivation, (6) facilitators and organizers of pasraman provide assistance, and (7) the facilitator and organizer of pasraman illustrative examples or stories. Upakara specifically on the matter of practice, the participants are given pasraman more emphasis on the value aspect of Hinduism, in which before the manufacturing process begins of upakara, pasraman participants must cleanse themselves apart physically and non-physically through prayer to God.

Evaluation activities of participants in this pasraman kilat include: Pretest, namely pasraman evaluation before the first meeting which was held on July 1, 2015, and posttest, ie evaluation after implementation of pasraman held on July 10, 2015. This evaluation uses a form of non-test or questionnaire, namely a number of written questions that are used to obtain information of participants of pasraman in the sense of personal statements, or things that are in the know. The use of the instrument type of questionnaire aims to determine the increase in spiritual values of 
Hindu teenagers before and after receiving the material of pasraman kilat. The results of the statistical tests can see the following table:

Test Statistics ${ }^{b}$

\begin{tabular}{|l|r|}
\hline & Posttest - Pretest \\
\hline$Z$ & $-3.927 \mathrm{a}$ \\
Asymp. Sig. (2-tailed) & .000 \\
\hline
\end{tabular}

a. Based on negative ranks.

b. Wilcoxon Signed Ranks Test

The test results of statistical tests above, the critical region is rejected if the value Asymp.Sig. < value of $a$. Result of calculation of the above, can be obtained Asymp.Sig value. $=0,000<$ value of $\alpha=52$, so that it can be concluded the null hypothesis $\left(H_{0}\right)$ was rejected, which means that there are differences in spiritual values before and after getting pasraman kilat. As with the calculation using statistical test, if in view of the average scores and posttest pretests $=78=110$, there is an increase in the spiritual values of Hindu teenagers as participants of pasraman kilat from before to after following a pasraman kilat. And thus it can be concluded that pasraman kilat has an effective increase spiritual values of Hindu teenager in Padangsambian, Denpasar. In statistics can be explained that: 1) there is the effect of pasraman kilat towards spiritual values, 2) there is an increased score of spiritual values after get pasraman when compared with before getting pasraman kilat.

\section{Conclusion}

Research and development are carried out has been completed and achieve the set goals, namely to produce a model of pasraman kilat to enhance the spiritual values of Hindu teenager. Increased spiritual values is actualized through the addition of knowledge, skills and attitudes. Based on the formulation of the problem and research objectives, which are connected with the results of research and discussion, it can be deduced as follows: 
1. The objective situation of pasraman kilat in Padangsambian, Denpasar based on the results of research shows that increased spiritual values has not been a priority in the effort to develop the ability through pasraman kilat implemented. Pasraman kilat implementation in practice has not fully follow the principles of good learning, such as planning, implementation and evaluation. Pasraman kilat also does not touched the teenagers who do not attend school, which actually become the preferred target. In addition to these trends has been implemented pasraman kilat which is often not touched on the discussion about values, especially spiritual values, the impact ispasraman kilat participants concerned with knowledge (cognitive) as a provision in answering the exam at school. Though spiritual values is the highest peak of awareness in religious teachings in life.

2. The conceptual model of pasraman kilat was developed using aguronguron system or asewakadharma with participative approach, and the integration between tattwa, moral and ceremonial skills/ upakara.

3. Implementation of the pasraman kilat model using aguron-guron system or asewakadharma, which means that the quest for knowledge and skills, ongoing in various places and times by means of a deliberate people who are knowledgeable and skilled. In pasraman kilat, aguron-guron system or asewakadharma carried out before, during and after pasraman kilat. Those indicate that participants were involved in the search for knowledge and skills from planning, implementation, evaluation and post pasraman kilat. Relationship between facilitators and participants did not stop after the implementation pasraman kilat ended, but continues in the context of guru sisya, where an ongoing relationship in order to establish active communication and motivation and never ending learning. Besidesupakara, the internalization process of spiritual values through counsel, exemplary, habituation and mentoring are also going well, so that participants have the confidence that the goal of life is jagadhita and moksha. While the effectiveness ofpasraman kilat models have a positive impact, both to participants and to the organizers of pasraman kilat. The level of acceptance of the participants of the materials developed in the model that is implemented high. 


\section{Bibliography}

Abubakar and Anwar. (2015). Learning Materials in Character Education (The Analysis of the Sociology Teaching at the Senior Hight School Banda Aceh, Indonesia). Jurnal Ilmiah Peuradeun, 3 (3), 405-416

Arif, Z. (1995). Andragogi. Bandung: Angkasa

Arikunto, S. (2002). Prosedur Penelitian Suatu Pendekatan Praktek. Jakarta: Rineka Cipta.

Borg. R.W. dan Gall M. D. (1989). Educational Research: An Introduction. New York: Longman

Hurlock, E. (1991). Psikolgi Perkembangan Suatu Pendekatan Sepanjang Rentang Kehidupan (Terjemahan oleh Istiwidayanti dan Soedjarwo). Jakarta: Penerbit Erlangga.

Jacius, M. J. (1974). Growing Old in the Twentieth Century. London: Routledge

Jan Jonker, dkk.(2011). Metodologi Penelitian. Panduan Untuk Master Ph.D di bidang Manajemen. Jakarta : Salemba Empat

Karibi, R. A. I. N. (2015). Religion, Human Rights and the Challenges of Freedom. Jurnal Ilmiah Peuradeun, 3(1), 39-54.

Lvina, E. (2015). The Role of Cross-Cultural Communication Competence: Effective Transformational Leadership Across Cultures. Jurnal Ilmiah Peuradeun, 3(1), 1-18.

Marheni, A. (2010). "Perkembangan Psikososial dan Kepribadian Remaja", dalam Tumbuh Kembang Remaja dan Permasalahannya. Jakarta: CV. Sagung Seto.

Rouhana, H. (2015). Feminism National Identity (Study on Experience of Palestinian Women in Israel and Muslim Women in India). Jurnal Ilmiah Peuradeun, 3(3), 353-362

Vohra, S. (2015). The Perspective of Hinduism About The Practice Of Dowry. Jurnal Ilmiah Peuradeun, 3(3), 363-370

Wirawan (2002). Psikologi Remaja. Jakarta : PT. BPK Gunung Mulia.

Zaltman, G., Duncan, R., dan Holbek, J. (1972). Innovation and Organization. Toronto: Interscience Publication John Wiley and Son. 